\title{
A NEW DINOFLAGELLAGE CYST SEQUENCE BIOSTRATIGRAPHIC FRAMEWORK FOR THE MIOCENE OF THE BALTIMORE CANYON TROUGH AND ADJACENT SALISBURY EMBAYMENT.
}

VERTEUIL*, Laurent de; NORRIS, Geoffrey, Dept. of Geology, University of Toronto, Earth Sciences Centre, 22 Russell St., Toronto, Ontario, Canada, M5S 3B1.

Over the past two decades, extensive seismic mapping of the Baltimore Canyon Trough off New Jersey, Delaware and Virginia, has documented a succession of progradational Miocene stratigraphic sequences. Understanding the depositional timing of these sequences is critical in evaluating the role of eustasy in their development, but has until now been hampered by the lack of suitably high resolution biostratigraphic data. Attempts to produce an integrated Neogene basin history have previously been frustrated by an inability to directly correlate individual shelf-based seismic sequences, with regionally mapped onshore, unconformity-bound, stratigraphic units. This study addresses both problems using data comprising the stratigraphic distribution of dinoflagellate cysts in two composited outcrop and ten subsurface sections from the Salisbury Embayment and adjacent Baltimore Canyon Trough. The result is a detailed age model for the entire Miocene depositional history of the area. Onshore samples are from the type sections of the Chesapeake Group in Maryland and Virginia. Offshore COST B-2 \& B-3, Exxon 684 \& 902 and Mobil 500 wells are directly tied to the regional seismic grid.

According to our model; the magnitude and timing of mapped sequences in the Baltimore Canyon Trough compare well with Miocene third order cycles of the Exxon Cycle Chart. With the exception of the 22 Ma sequence (Cycle 1.5 of Haq et al., 1988), all of the other postulated eustatically controlled sequences are potentially present in the study area. In addition, on the basis of seismic mapping and integrated biostratigraphy, our model predicts one additional lower Serravalian sequence between 15.5 Ma and 13.8 Ma, and two additional lower Tortonian sequences between 10.5 Ma and 8.2 Ma. The onshore expression of these sequences are, respectively, the Calvert Beach Member of the Calvert Formation and parts of the Little Cove Point Beds of the Saint Marys Formation. An important implication of the age model is that the entire Fairhaven Member and "beds 4-9" of the Plum Point Marl Member, of the Calvert Formation, are lower Miocene strata.

These dinocyst data were not available when the Exxon model of Miocene eustatic cycles was developed and therefore represent a critical independent test of that model. This is particularly so because the tectonically quiescent, mature, divergent-margin setting of the basin limits the role of causative variables other than eustasy, in the development and architecture of third order depositional sequences. Our model should be further tested by detailed sedimentological and taphonomic field studies of the Chesapeake Group. 